\title{
Probabilistic Modelling for Incorporating Uncertainty in Least Cost Path Results: a Postdictive Roman Road Case Study
}

\author{
Joseph Lewis ${ }^{1}$ (iD
}

Accepted: 18 March 2021/ Published online: 27 March 2021

(C) The Author(s) 2021

\begin{abstract}
The movement of past peoples in the landscape has been studied extensively through the use of least cost path (LCP) analysis. Although methodological issues of applying LCP analysis in archaeology have frequently been discussed, the effect of DEM error on LCP results has not been fully assessed. Due to this, the reliability of the LCP result is undermined, jeopardising how well the method can confidently be used to model past movement. To strengthen the reliability of LCP results, this research proposes the use of Monte Carlo simulation as a method for incorporating and propagating the effects of error on LCP results. Focusing on vertical error, random error fields are calculated and incorporated into the documented and reproducible LCP modelling process using the R package leastcostpath. By graphically communicating the impact of vertical error using probabilistic LCPs, uncertainty in the results can be taken into account when interpreting LCPs. The method is applied to a Roman road case study, finding that the incorporation of vertical error results in the identification of multiple 'least cost' routes within the landscape. Furthermore, the deviation between the roman road and the probabilistic LCP suggests that the location of the roman road was influenced by additional factors other than minimising energy expenditure. This research finds that the probabilistic LCP derived using Monte Carlo simulation is a viable method for the graphical communication of the uncertainty caused by error within the input data used within the LCP modelling process. Therefore, it is recommended that probabilistic LCPs become the default approach when modelling movement using input data that contains errors.
\end{abstract}

Keywords Least cost path · Error propagation - Uncertainty · Monte Carlo · Movement . Roman roads

Joseph Lewis

J12094@cam.ac.uk

1 Department of Archaeology, University of Cambridge, Cambridge, UK 


\section{Introduction}

The movement of past peoples in the landscape has been studied extensively through the use of least cost path (LCP) analysis (Verhagen et al., 2019; White \& SurfaceEvans, 2012). LCP analysis is based on the premise that humans will economise their behaviour (Zipf, 1949). Thus, when travelling in a landscape, humans will attempt to optimise the cost of travel by choosing the path of least cost (Surface-Evans \& White, 2012). Therefore, the likelihood of interaction between humans and the landscape is assumed to be related to the ease of access, with easy-to-access areas expected to show traces of human activity (Surface-Evans \& White, 2012). This ease of access is represented as a cost surface, which quantifies the ease or difficulty of crossing between individual cells in a raster grid (Collischonn \& Pilar, 2000). The cost surface is then used to create an accumulated cost surface, which represents the accumulated cost of moving away from a specific starting cell (Yu et al., 2003). Finally, the least costly path from another cell to the starting cell is calculated (Herzog, 2014a; Howey, 2007).

The input data, and the resultant cost surface, is therefore foundational in the calculation of the LCP. In particular, the digital elevation model (DEM), which forms the basis of the majority of archaeological LCP studies (Herzog, 2010; Verhagen, 2018), is often used as an error-free model of the topography (Wechsler \& Kroll, 2006). Whilst the impact of DEM resolution on the cost surface and the LCP has been explored (e.g. Branting, 2012; Harris, 2000; Herzog, 2014a), the effects of horizontal and vertical error are rarely discussed (for exceptions see Herzog \& Posluschny, 2011; Herzog \& Yépez, 2015a, 2015b; Verhagen et al., 2019). Instead, cost surfaces and LCPs are often viewed as 'infallible' (Brouwer Burg, 2017), ignoring that they were derived from a DEM containing random errors: that is, errors accrued from mistakes during the creation of the DEM (Fisher \& Tate, 2006). This random error in the DEM can have significant consequences on the computed LCP, given the extreme sensitivity of LCPs to small changes in variables (Kantner, 2012, p. 234). Due to this, the reliability of the LCP as a heuristic device for understanding past human movement is undermined, jeopardising how well the method can confidently be used to identify long-distance routes (e.g. Batten, 2007; Palmisano, 2017), to understand trade networks (e.g. Bell et al., 2002; Fábrega Álvarez \& Parcero Oubiña, 2007; Murrieta-Flores, 2012) and to assess which factors influenced the location of routes (Bell \& Lock, 2000; Fonte et al., 2017; Güimil-Fariña \& Parcero-Oubiña, 2015; Herzog, 2017; Kantner \& Hobgood, 2003; Verhagen et al., 2019; Verhagen \& Jeneson, 2012).

Whilst errors in the DEM can be reduced through the use of high-resolution, highaccuracy DEMs derived from sources such as lidar (light detection and ranging), error cannot be fully eliminated (Aguilar et al., 2010; Hodgson \& Bresnahan, 2004). Thus, the error in the DEM, although reduced, still propagates into uncertainty in the LCP result. Therefore, this research proposes that instead of ignoring the error in the input data, and the subsequent LCP, the error in the DEM should be incorporated through the use of uncertainty propagation. By doing this, the resultant LCP is viewed probabilistically. That is, each LCP based on input data incorporating different realisations of the error is aggregated to form a 'density of LCPs' that graphically communicates how the error impacts the LCP, as well as identifying the most probable location of the LCP after error has been accounted for. From this, the reliability of the LCP is strengthened by yielding outcomes that better approximate reality, or in other words, the LCP and 
their interpretation is less susceptible to change if the LCP modelling process is run with the same input data incorporating a different, but equally likely, realisation of error.

Although the use of uncertainty propagation can be applied to all input data containing errors within the LCP modelling process, this research focuses on the impact of vertical error on the calculated LCP. This is demonstrated through a case study that aims to postdictively model a Roman road in Cumbria, England.

\section{Methodological Proposal}

In order to propagate the effects of vertical error on LCP results, this research proposes the use of Monte Carlo simulation (Brouwer Burg et al., 2016; Hunter \& Goodchild, 1997; Zhang \& Goodchild, 2003). Monte Carlo simulation has been used extensively for the modelling of DEM uncertainty in viewshed analysis (e.g. Fisher, 1991, 1992; Nackaerts et al., 1999), flooding (e.g. Cooper et al., 2015; Gesch, 2018; Gesch et al., 2020; Hawker et al., 2018; Leon et al., 2014) and slope failure prediction (e.g. Davis \& Keller, 1997; Holmes et al., 2000; Zhou et al., 2003). By incorporating different realisations of the vertical error, which is measured as the average positive or negative deviation between ground-based observations and DEM values at a set of control points and reported as the root mean square error (RMSE), the impact of vertical error on the model output can be evaluated (Heuvelink, 1998; Zhang \& Goodchild, 2003, p. 94). That is, for $n$ simulation runs, $n$ random error field realisations drawn from a normal distribution of mean $=0$ and standard deviation $=$ DEM's vertical error are generated (Fig. 1(A)) and individually added to the DEM (Hunter \& Goodchild, 1997) (Fig. 1(B)). The $n$ DEMs are then used to compute $n$ cost surfaces (Fig. 1(C)), with each cost surface incorporating different realisations of the vertical error. Each cost surface is then used to calculate a LCP (Fig. 1(D)), resulting in $n$ LCPs. Therefore, each LCP can be viewed as a deterministic realisation from an equally likely realisation of the true elevation surface. From this, the $n$ LCPs can be viewed probabilistically - that is, the likelihood of the LCP crossing a raster cell can be communicated by calculating the number of times an LCP crosses a cell divided by the total number of simulations (Fig. $1(\mathrm{E}))$.

\section{Package Overview}

In order to make the incorporation of vertical error reproducible and accessible to other researchers (Marwick, 2017), the method has been implemented into the $\mathrm{R}$ package leastcostpath (Lewis, 2020). The package is available at https://github.com/ josephlewis/leastcostpath and https:/cran.r-project.org/web/packages/leastcostpath and includes the function add_dem_error() for the calculation and addition of a random error field to the DEM (i.e. it automates steps A and B in Fig. 1).

The package leastcostpath is built on the classes and functions in the $\mathrm{R}$ package gdistance (van Etten, 2017). According to van Etten (2017), the results from gdistance are comparable to other software such as ArcGIS and GRASS. The package gdistance converts the raster map to a sparse matrix representing conductance between adjacent 


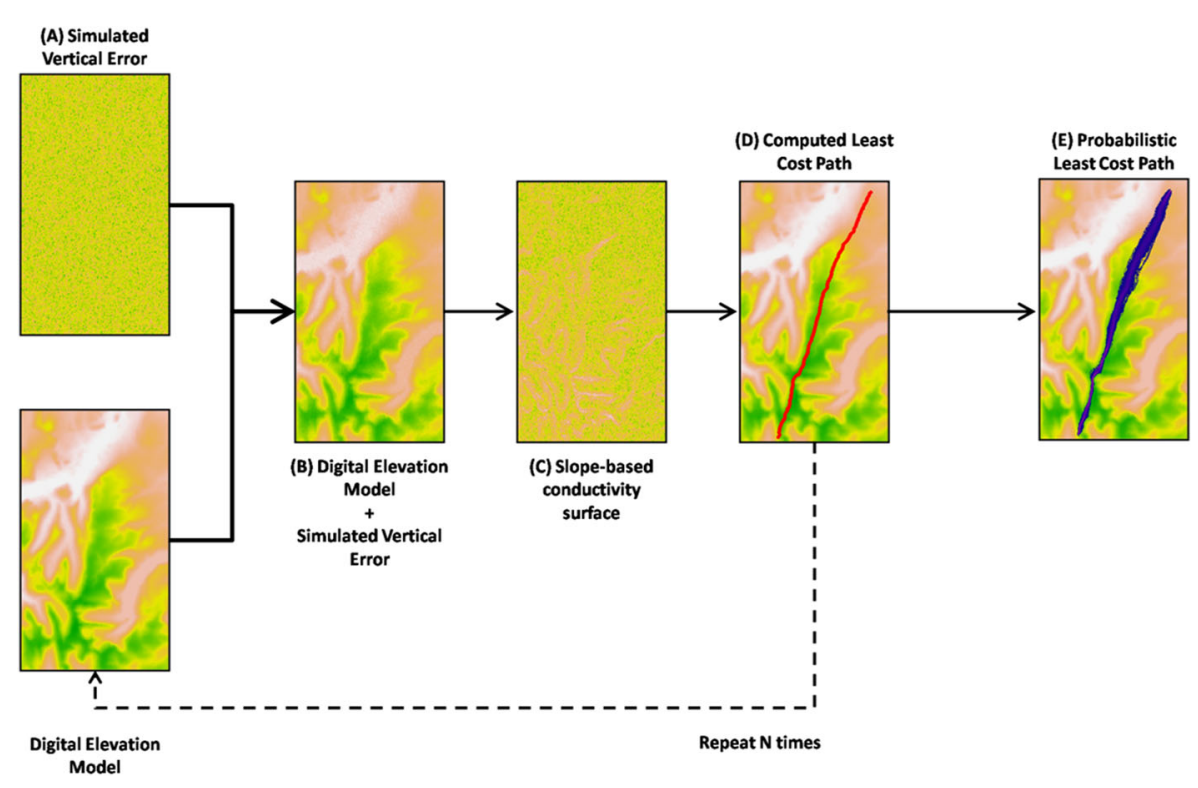

Fig. 1 Flowchart of vertical error uncertainty propagation in least cost path analysis (A to $\mathbf{E}$ )

cells (van Etten, 2017). The use of conductance, which is the ease in which movement can occur between adjacent cells, is in contrast to other GIS software, where calculations are done using cost, friction or resistance values (van Etten, 2017). Sparse matrices are efficient data structures that are especially suitable for LCP analysis given that the connectivity of cells in a raster map is often limited to adjacent cells only, with the vast majority of cells not connected, and thus having a conductance value of zero (van Etten, 2017). The R package leastcostpath utilises these sparse, or conductivity, matrices to represent conductivity through a landscape. By calculating and storing conductivity from each raster cell to all other adjacent raster cells based on a usersupplied function, both isotropic (conductivity neither benefited nor hindered by direction) and anisotropic costs (conductivity is direction-dependent) can be incorporated into the LCP analysis (Conolly \& Lake, 2006, pp. 217-221; Wheatley \& Gillings, 2002, pp. 137-140). For example, slope is anisotropic, with movement up-slope normally involving higher costs than movement down-slope (Herzog, 2014a, b). Therefore, by calculating the slope in all directions and preserving the anisotropic property of slope, the LCP can differ depending on whether it is calculated from A to B or B to A (Herzog, 2014a).

\section{Case Study: the 'High Street' Roman road}

\section{Background}

During the late first century A.D. and early second, forts north of the Tyne-Solway isthmus were abandoned (Breeze \& Dobson, 1985). The forts of Brougham and Ambleside were subsequently built and occupied (Breeze, 1988) (Fig. 2). The High 


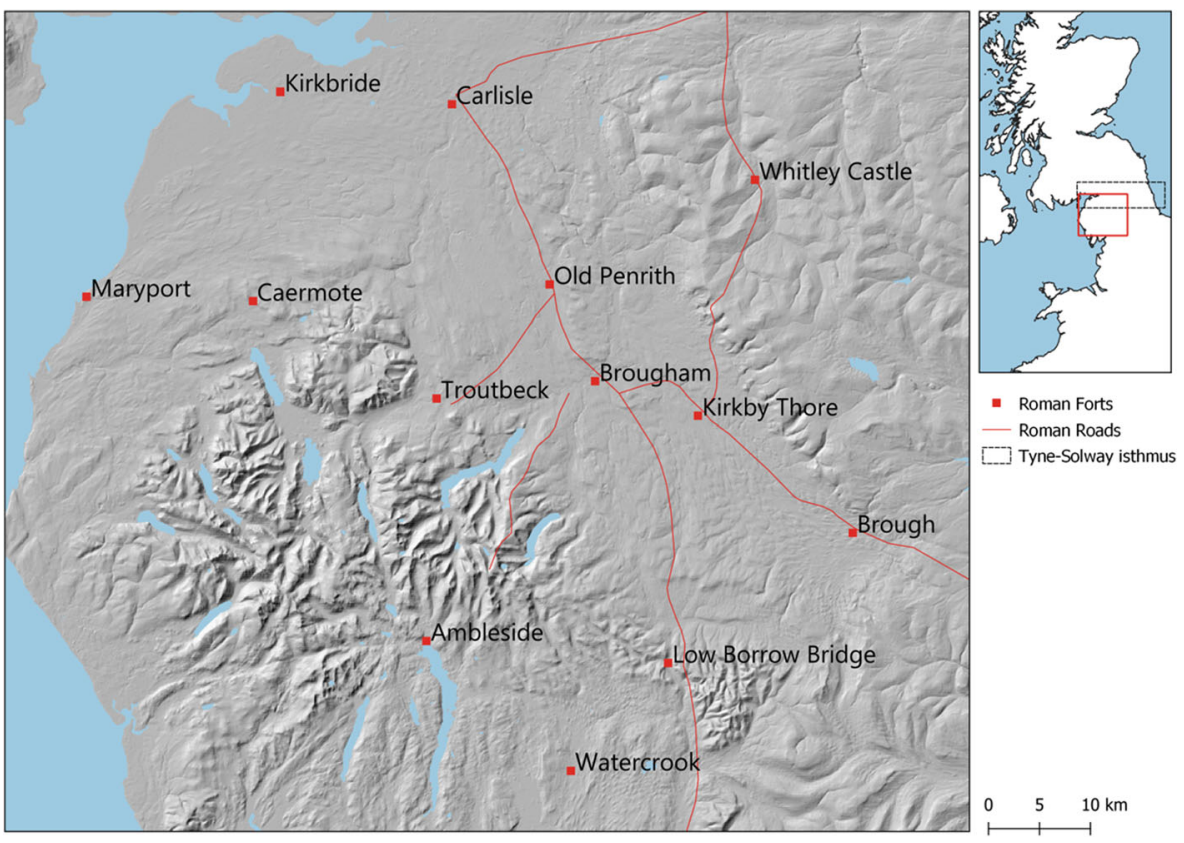

Fig. 2 Military dispositions in North-West England in AD 95. Based on Breeze and Dobson (1985, p. 6)

Street Roman road (Fig. 3), likely built during the late first or early second century A.D. (Breeze \& Dobson, 1985, p. 6; Hindle, 1998; Shotter, 2004, p. 53), is thought to have connected these two forts and provided connection to the main-western route to Carlisle (Codrington, 1919, pp. 155-157; Cool, 2007, p. 55; Shepherd, 2004, p. 29).

\section{Data and Methods}

\section{High Street Roman Road}

In order to assess the similarity in location between the computed LCPs and the Roman road, the known route of the High Street Roman road is required. Despite the location of the Roman road being available from other sources (e.g. Bishop, 2014; Talbert, 2000), the extant route of the Roman road was recorded by Whitehead and Elsworth (2008) during an archaeological evaluation of the area. This represents the most accurate polygonal representation of the Roman road available, whilst also only including that which can be identified in the field (see Collingwood, 1930, p. 118; Nicholson, 1861, p. 7 for speculation on northern and southern sections). The location of the Roman road was retrieved from the Historic England Scheduled Monuments via https:/historicengland.org.uk/listing/the-list/data-downloads/ (List Entry - 1003275).

\section{Digital Elevation Model}

The OS Terrain 50 DEM (50m resolution and 4m RMSE) (Ordnance Survey, 2020) was used throughout this case study. The OS Terrain 50 DEM is based on the modern topography, and does not, therefore, represent the topography during the Roman 


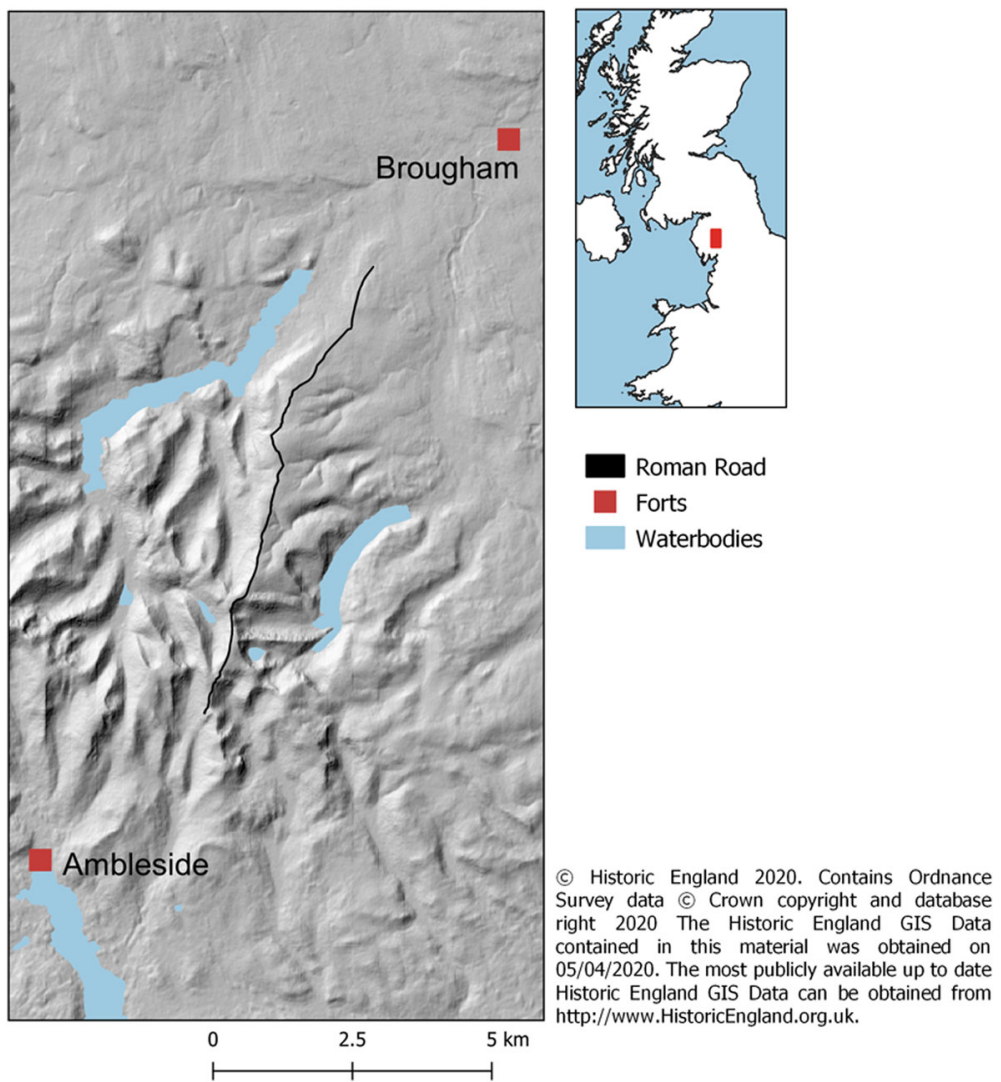

Fig. 3 High Street Roman road connecting the Roman forts of Brougham and Ambleside

period. Although this means that the DEM incorporates modern features such as the Haweswater and Kentmere Reservoir, this study is focused on the use of LCP analysis in the modelling of the Roman road along the 'High Street' ridgeway. Due to the high elevation of the ridgeway, the produced LCP is therefore assumed to be unaffected by these modern constructions. Furthermore, whilst the resolution of the DEM has been noted to have an impact on LCP results (Conolly \& Lake, 2006, pp. 101-102; Herzog \& Yépez, 2015b; Verhagen et al., 2019), with Kantner (2012) recommending the use of DEMs with a resolution of under $30 \mathrm{~m}$, computational limitations necessitated the use of the $50 \mathrm{~m}$ DEM over more accurate data sources such as the OS Terrain 5 DEM $(5 \mathrm{~m}$ resolution and 2.5m RMSE) (Ordnance Survey, 2017). However, it should be noted that although a lower resolution DEM was used within this case study, the consequences of vertical error will be present in a DEM regardless of its resolution, and therefore, the results of this study are applicable to all DEM-based least cost analyses. For interested readers, the limitations were imposed due to the size of the raster when calculating the cost surface. That is, the OS Terrain 50 DEM raster has 51,744 cells. Contrast this with the OS Terrain 5 DEM, which has 5,177,480 cells, and required more than $24 \mathrm{~GB}$ of RAM to calculate the cost surface. Nonetheless, as this case study is explicitly focused on the impact of vertical error on the LCP results, and not DEM resolution, the use of the lower resolution DEM is therefore deemed justifiable. 


\section{Computing the Cost Surface}

In order to represent cost of movement between adjacent cells within the DEM, Llobera and Sluckin's (2007) symmetric quadratic cost function was applied to the calculated slope values. The use of Llobera and Sluckin's (2007) energy expenditure cost function over the more familiar time-based Tobler's Hiking Function (Tobler, 1993) reflects previous success in its ability to model Roman roads (e.g. Fonte et al., 2017; GüimilFariña \& Parcero-Oubiña, 2015; Parcero-Oubiña et al., 2019). Furthermore, in line with the recommendation by Harris (2000), a 48-neighbourhood kernel was used - that is, each cell in the cost surface is deemed to be adjacent, and therefore connected, to 48 neighbouring cells. Due to this, the elongation error, which is the difference in length between the optimal straight line and the LCP, is reduced to below $1.4 \%$ (Huber \& Church, 1985), resulting in more accurate cost accumulation (Harris, 2000; Herzog, 2014a; Wheatley \& Gillings, 2002, pp. 142-144).

\section{Incorporating Vertical Error and Computing the Probabilistic Least Cost Path}

In order to propagate the effects of vertical error on LCP results, 1000 realisations of random error fields were calculated. Although Heuvelink (1998, p. 45) noted that 100 Monte Carlo realisations should be enough, 1000 realisations ensure that the results are stable and unlikely to change. It should be noted, however, that the number of realisations could be decreased by assessing when the results converge. That is, assessing when increasing the number of LCPs does not change the overall spatial pattern of the probabilistic LCP. The error fields representing vertical error within the DEM were generated from random values drawn from a normal distribution of mean $=0$ and standard deviation $=4$ (i.e. the RMSE of the DEM) (Fisher, 1998; Fisher \& Tate, 2006; Wechsler \& Kroll, 2006). To ensure that the random error fields were spatially autocorrelated with themselves, a mean $77 \times 77$ filter was applied (Wechsler \& Kroll, 2006). That is, the values in each random error field were replaced with a mean of the values within a moving $77 \times 77$ window. This results in the values within each random error field being less different when they are nearer to each other and more different when they are further away. The window size of $77 \times 77$ was derived through the use of a semivariogram based on the DEM (Wechsler \& Kroll, 2006). The range, which indicates the maximum distance at which spatial autocorrelation is present (Oliver \& Webster, 2015, pp. 30-32), was identified as being $3820.6 \mathrm{~m}$, thus the $77 \times 77$ window (3820.6/50 $\mathrm{m}$ resolution of DEM). The spatially correlated random error fields were then added to the DEM, resulting in 1000 DEMs each incorporating different realisations of the random error field (steps A and B in Fig. 1). The DEMs were then corrected for unrealistic geomorphology that might have been introduced when adding the random error field (Temme et al., 2009, p. 131). This was achieved through the use of a sink fill algorithm, which removes surface depressions in DEMs (Choi, 2018; Wang \& Liu, 2006). From this, 1000 cost surfaces were calculated (step D in Fig. 1). Lastly, 1000 least cost paths were computed, with the probabilistic LCP generated by calculating the number of times an LCP crosses a raster cell divided by the total number of simulations (step E in Fig. 1). 


\section{Results}

\section{Least Cost Paths Without and With Vertical Error}

When visually comparing the LCPs (Fig. 4), it is apparent that the single LCP produced without incorporating vertical error (Fig. 4(A)) does not fully capture nor communicate how the vertical error in the DEM, and subsequently the cost surface, propagates to the LCP result. In contrast, the probabilistic LCP (Fig. 4(B)), through incorporating vertical error, and its uncertainty, has identified multiple 'least cost' routes within the southern section of the Roman road. Similarly, the probabilistic LCP has identified two routes of either side of the Roman road in the centre of the study area, with one deviating southwards towards the lower elevation. Finally, the probabilistic LCP has identified that the large deviation from the Roman road in the northern section remains after vertical error is accounted for.

\section{Discussion and Conclusions}

The case study demonstrates how the effect of vertical error in the DEM, and the subsequent cost surface, propagates through the LCP modelling process. Whilst the LCPs calculated

a

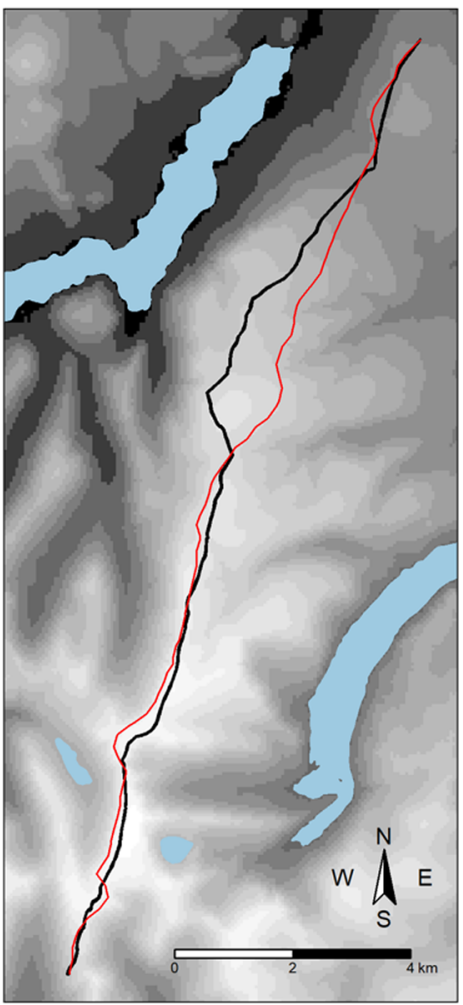

b

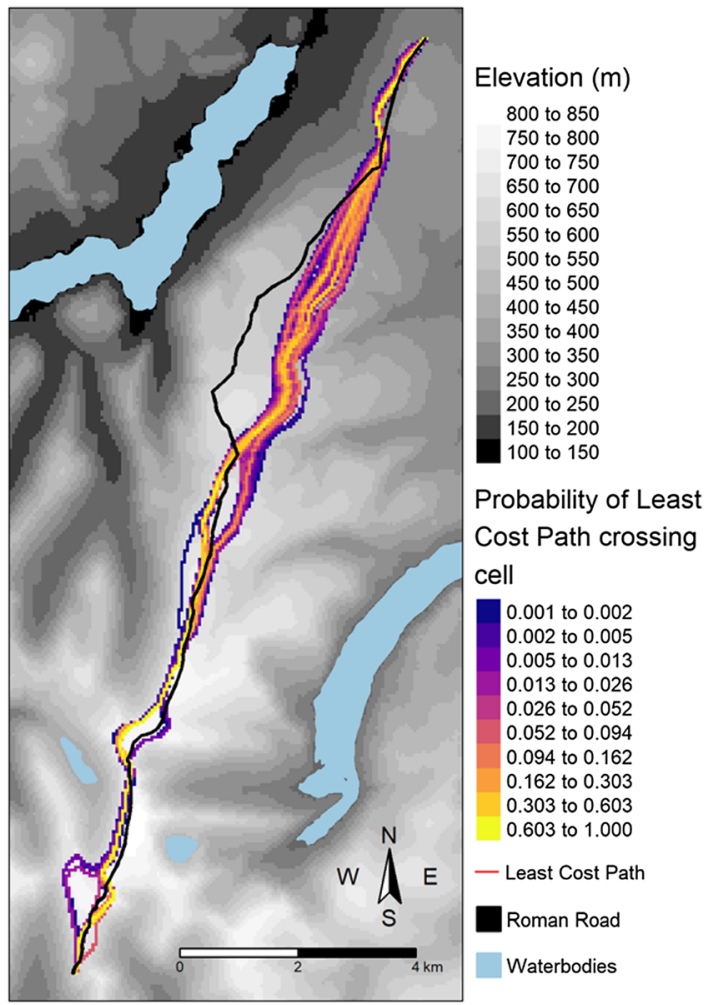

Fig. 4 Least cost paths without (A) and with vertical error incorporated (B) 
without and with vertical error shared similarities in their trajectories, the use of probabilistic LCPs has identified that the vertical error within the DEM most influences the location of the calculated LCP in the southern section of the study area. More specifically, the probabilistic LCP has identified three different routes that the LCP could have taken, dependent on a different, but equally likely, realisation of vertical error within the DEM. However, by quantifying the likelihood of the LCP crossing each raster cell, it is apparent that the route following the Roman road is more probable and is therefore a more credible location for the LCP after vertical error is accounted for. Similarly, the two identified routes in the centre of the study area show that the vertical error within the input data, and the subsequent cost surface, impacts which route is more probable, and therefore which better reflects reality. In contrast, the probabilistic LCP has identified one main route in the northern section of the study area. However, unlike the southern section, the Roman road in the northern section does not follow the LCP - that is, the least costly path used when trying to minimise energy expenditure when moving through the landscape. The lack of similarity, therefore, suggests that the location of the Roman road in the northern section may have been influenced by other factors, for example visibility (e.g. Verhagen \& Jeneson, 2012).

Nonetheless, by incorporating and propagating the effect of vertical error in the LCP modelling process, the vertical error within the DEM is accounted for, therefore increasing the reliability that the LCP yields outcomes that better approximates reality. Furthermore, the uncertainty caused by vertical error on the LCP result in the southern and centre section of the study area suggests that higher accuracy DEMs should be used when conducting least cost path analyses. Through this, the uncertainty in the LCP result caused by the vertical error within the DEM will be reduced. It should be noted, however, that there are still errors in the DEM not accounted for. For example, the impact of horizontal error on the LCP results has not been assessed, whilst the 50-m resolution of the DEM averages the 'true' elevation surface, and therefore introduces error. Therefore, further research is needed on the assessment of how different errors impact DEMs, their subsequent cost surfaces and when these errors are deemed to have minimal effect on the LCP results.

The most significant contribution of this research lies in the explicit propagation of error on LCP results. By formally incorporating error into the LCP modelling process, uncertainty is quantified, resulting in LCP results of increased reliability. Furthermore, the use of probabilistic LCPs has shown to successfully communicate the uncertainty caused by error, as well as allowing for the identification of multiple potential routes that are the result of different, but equally likely, realisations of error. The quantification of uncertainty on LCP results is therefore of fundamental importance. It is through the explicit acknowledgement that the digital elevation model is not an error-free model of topography that we can aim to confidently use our LCP models as heuristic devices for understanding past human movement, irrespective of the geographical or cultural context. Until then, interpretations of human actions based on LCP models are biased. This research therefore suggests that the use of uncertainty propagation via Monte Carlo simulation is appropriate not just for vertical error but any error that needs to be quantified and visualised when conducting least cost path analysis, or working with cost surfaces more generally.

Acknowledgements I would like to thank Sian Gilbert for commenting on early drafts of this text. I would also like to thank the three reviewers at PCI Archaeology who peer-reviewed and recommended the manuscript (https://doi.org/10.24072/pci.archaeo.100005), Dr. Crema for his thoughtful suggestions, and the 
three reviewers for their comments, though of course, all mistakes are my own. The analysis have been conducted in R (R Core Team, 2018) using the libraries DMMF (Choi, 2018), gdistance (van Etten, 2017), gstat (Pebesma, 2004), leastcostpath (Lewis, 2020), raster (Hijmans, 2020), rgdal (Bivand et al., 2019), rgeos (Bivand \& Rundel, 2020), sp (Pebesma \& Bivand, 2005) and tmap (Tennekes, 2018).

Availability of Data and Material https:/github.com/josephlewis/Incorporating-Uncertainty-in-Least-CostPath-Modelling

Code Availability https:/github.com/josephlewis/Incorporating-Uncertainty-in-Least-Cost-Path-Modelling

Author Contribution Joseph Lewis - conceptualisation; data curation; formal analysis; investigation; methodology; software; validation; visualisation

\section{Declarations}

Competing Interests The author declares no competing interests.

Open Access This article is licensed under a Creative Commons Attribution 4.0 International License, which permits use, sharing, adaptation, distribution and reproduction in any medium or format, as long as you give appropriate credit to the original author(s) and the source, provide a link to the Creative Commons licence, and indicate if changes were made. The images or other third party material in this article are included in the article's Creative Commons licence, unless indicated otherwise in a credit line to the material. If material is not included in the article's Creative Commons licence and your intended use is not permitted by statutory regulation or exceeds the permitted use, you will need to obtain permission directly from the copyright holder. To view a copy of this licence, visit http://creativecommons.org/licenses/by/4.0/.

\section{References}

Aguilar, F. J., Mills, J. P., Delgado, J., Aguilar, M. A., Negreiros, J. G., \& Pérez, J. L. (2010). Modelling vertical error in LiDAR-derived digital elevation models. ISPRS Journal of Photogrammetry and Remote Sensing, 65(1), 103-110. https://doi.org/10.1016/j.isprsjprs.2009.09.003.

Batten, D. C. (2007). Least-cost pathways, exchange routes, and settlement patterns in Late Prehistoric EastCentral New Mexico. In Computer Applications and Quantitative Methods in Archaeology, J. T. Clark, \& E. M. Hagemeister (Eds.), Digital discovery: exploring new frontiers in human heritage : CAA 2006 : computer applications and quantitative methods in archaeology (pp. 151-158). Archaeolingua: Budapest.

Bell, T., \& Lock, G. R. (2000). Topographic and cultural influences on walking the Ridgeway in later prehistoric times. In G. R. Lock (Ed.), Beyond the map: archaeology and spatial technologies (pp. 85100). Amsterdam; Washington, DC: Tokyo: IOS Press; Ohmsha [distributor].

Bell, T., Wilson, A., \& Wickham, A. (2002). Tracking the Samnites: landscape and communications routes in the Sangro Valley, Italy. American Journal of Archaeology, 106(2), 169-186. https://doi.org/10.2307/ 4126242.

Bishop, M. C. (2014). The secret history of the Roman roads of Britain. Barnsley, South Yorkshire: Pen \& Sword Military.

Bivand, R., \& Rundel, C. (2020). rgeos: Interface to Geometry Engine - Open Source ('GEOS'). https:// CRAN.R-project.org/package=rgeos.

Bivand, R., Keitt, T., \& Rowlingson, B. (2019). rgdal: bindings for the "Geospatial” Data Abstraction Library. https://CRAN.R-project.org/package=rgdal.

Branting, S. (2012). Seven solutions for seven problems with least cost pathways. In D. White \& S. L. Surface-Evans (Eds.), Least Cost Analysis of Social Landscapes: Archaeological Case Studies (pp. 209224). Salt Lake City: University of Utah Press.

Breeze, D. J. (1988). The Roman Army in Cumbria. Transactions of the Cumberland \& Westmorland Antiquarian \& Archaeological Society, 88, 9-22. 
Breeze, D. J., \& Dobson, B. (1985). Roman military deployment in North England. Britannia, 16, 1. https:// doi.org/10.2307/526389.

Brouwer Burg, M. (2017). It must be right, GIS told me so! Questioning the infallibility of GIS as a methodological tool. Journal of Archaeological Science, 84, 115-120. https://doi.org/10.1016/j.jas. 2017.05.010.

Brouwer Burg, M., Peeters, H., \& Lovis, W. A. (2016). Introduction to uncertainty and sensitivity analysis in archaeological computational modeling. In M. Brouwer Burg, H. Peeters, \& W. A. Lovis (Eds.), Uncertainty and sensitivity analysis in archaeological computational modeling (pp. 1-20). Cham: Springer International Publishing.

Choi, K. (2018). DMMF: daily based Morgan-Morgan-Finney (DMMF) Soil Erosion Model. https:/CRAN. R-project.org/package=DMMF.

Codrington, T. (1919). Roman roads in Britain (3rd ed.). London: Society for Promoting Christian Knowledge.

Collingwood, R. G. (1930). Five Notes. Transactions of the Cumberland and Westmorland Antiqurian and Archaeological Society, 30, 116-124.

Collischonn, W., \& Pilar, J. V. (2000). A direction dependent least-cost-path algorithm for roads and canals. International Journal of Geographical Information Science, 14(4), 397-406. https://doi.org/10.1080/ 13658810050024304.

Conolly, J., \& Lake, M. (2006). Geographical information systems in archaeology. New York, NY: Cambridge University Press.

Cool, H. E. M. (2007). Telling stories about Brougham, or the importance of the specialist report. In R. Hingley, S. Willis, \& University of Durham (Eds.), Roman finds: context and theory: proceedings of a conference held at the University of Durham (pp. 54-58). Oxford: Oakville, CT: Oxbow; Distributed in the USA by David Brown.

Cooper, H. M., Zhang, C., \& Selch, D. (2015). Incorporating uncertainty of groundwater modeling in sea-level rise assessment: a case study in South Florida. Climatic Change, 129(1-2), 281-294. https://doi.org/10. 1007/s10584-015-1334-1.

Davis, T. J., \& Keller, C. P. (1997). Modelling uncertainty in natural resource analysis using fuzzy sets and Monte Carlo simulation: slope stability prediction. International Journal of Geographical Information Science, 11(5), 409-434. https://doi.org/10.1080/136588197242239.

van Etten, J. (2017). R package gdistance: distances and routes on geographical grids. Journal of Statistical Software, 76(13). https://doi.org/10.18637/jss.v076.i13.

Fábrega Álvarez, P., \& Parcero Oubiña, C. (2007). Proposals for an archaeological analysis of pathways and movement. Archeologia e Calcolatori, 18, 121-140.

Fisher, P. (1991). First experiments in viewshed uncertainty: the accuracy of the viewshed area. Photogrammetric Engineering and Remote Sensing, 57(10), 1321-1327.

Fisher, P. (1992). First experiments in viewshed uncertainty: simulating fuzzy viewsheds. Photogrammetric Engineering and Remote Sensing, 57, 345-352.

Fisher, P. (1998). Improved modeling of elevation error with geostatistics. GeoInformatica, 2(3), $215-233$. https://doi.org/10.1023/A:1009717704255.

Fisher, P., \& Tate, N. J. (2006). Causes and consequences of error in digital elevation models. Progress in Physical Geography: Earth and Environment, 30(4), 467-489. https://doi.org/10.1191/ 0309133306pp492ra.

Fonte, J., Parcero-Oubiña, C., \& Costa-García, J. M. (2017). A Gis-Based Analysis Of The Rationale Behind Roman Roads. The Case Of The So-Called Via Xvii (Nw Iberian Peninsula). Mediterranean Archaeology and Archaeometry, 17, 163-189. https://doi.org/10.5281/zenodo.1005562.

Gesch, D. B. (2018). Best practices for elevation-based assessments of sea-level rise and coastal flooding exposure. Frontiers in Earth Science, 6, 230. https://doi.org/10.3389/feart.2018.00230.

Gesch, D. B., Palaseanu-Lovejoy, M., Danielson, J., Fletcher, C., Kottermair, M., Barbee, M., \& Jalandoni, A. (2020). Inundation exposure assessment for Majuro Atoll, Republic of the Marshall Islands Using a highaccuracy digital elevation model. Remote Sensing, 12(1), 154. https://doi.org/10.3390/rs12010154.

Güimil-Fariña, A., \& Parcero-Oubiña, C. (2015). "Dotting the joins": a non-reconstructive use of Least Cost Paths to approach ancient roads. The case of the Roman roads in the NW Iberian Peninsula. Journal of Archaeological Science, 54, 31-44. https://doi.org/10.1016/j.jas.2014.11.030.

Harris, T. (2000). Moving GIS: exploring movements within prehistoric cultural landscapes using GIS. In G. R. Lock (Ed.), Beyond the map: archaeology and spatial technologies (pp. 116-123). Amsterdam: IOS Press. 
Hawker, L., Rougier, J., Neal, J., Bates, P., Archer, L., \& Yamazaki, D. (2018). Implications of simulating global digital elevation models for flood inundation studies. Water Resources Research, 54(10), 79107928. https://doi.org/10.1029/2018WR023279.

Herzog, I. (2010). Theory and practice of cost functions. In Fusion of Cultures: Abstracts of the XXXVIII Conference on Computer Applications and Quantitative Methods in Archaeology (pp. 431-434). Granada: CAA 2010.

Herzog, I. (2014a). Least-cost paths - some methodological issues. Internet Archaeology, (36). https://doi.org/ 10.11141/ia.36.5.

Herzog, I. (2014b). A review of least cost analysis of social landscapes. Archaeological Case Studies [Book]. Internet Archaeology, (34). https://doi.org/10.11141/ia.34.7.

Herzog, I. (2017). Reconstructing pre-industrial long distance roads in a hilly region in Germany, Based on Historical and Archaeological Data. Studies in Digital Heritage, 1(2), 642-660. https://doi.org/10.14434/ sdh.v1i2.23283.

Herzog, I., \& Posluschny, A. (2011). Tilt - slope-dependent least cost path calculations revisited. In E. Jerem, F. Redö, \& V. Szevérenyi (Eds.), On the road to reconstructing the past: Computer Applications and Quantitative Methods in Archaeology (CAA): proceedings of the 36th International Conference, Budapest, April 2-6, 2008 (pp. 212-218). Budapest: Archaeolingua http://proceedings.caaconference. org/paper/cd31_herzog_posluschny_caa2008/. Accessed 22 December 2019.

Herzog, I., \& Yépez, A. (2015a). Analyzing patterns of movement and of settlement in the East-Andean Mountains of Ecuador. Vienna, Austria: Presented at the Conference on Cultural Heritage and New Technologies. November 8-10 https://www.chnt.at/wp-content/uploads/eBook_CHNT19_Herzog_ Yepez.pdf. Accessed 22 December 2019.

Herzog, I., \& Yépez, A. (2015b). The impact of the DEM on archaeological GIS studies: a case study in Ecudaor. Vienna: Presented at the Proceedings of the 19th International Conference on Cultural Heritage and New Technologies 2014 (CHNT 19, 2014) https://www.chnt.at/wp-content/uploads/eBook_ CHNT20 Herzog Yepez 2015.pdf. Accessed 5 October 2020.

Heuvelink, G. B. M. (1998). Error propagation in environmental modelling with GIS. London; Bristol, PA: Taylor \& Francis.

Hijmans, R. J. (2020). raster: geographic data analysis and modeling. https://CRAN.R-project.org/package= raster

Hindle, B. P. (1998). Roads and tracks of the Lake District (Rev. ed.). Milnthorpe: Cicerone.

Hodgson, M. E., \& Bresnahan, P. (2004). Accuracy of airborne Lidar-derived elevation. Photogrammetric Engineering \& Remote Sensing, 70(3), 331-339. https://doi.org/10.14358/PERS.70.3.331.

Holmes, K. W., Chadwick, O. A., \& Kyriakidis, P. C. (2000). Error in a USGS 30-meter digital elevation model and its impact on terrain modeling. Journal of Hydrology, 233(1-4), 154-173. https://doi.org/10. 1016/S0022-1694(00)00229-8.

Howey, M. C. L. (2007). Using multi-criteria cost surface analysis to explore past regional landscapes: a case study of ritual activity and social interaction in Michigan, AD 1200-1600. Journal of Archaeological Science, 34(11), 1830-1846. https://doi.org/10.1016/j.jas.2007.01.002.

Huber, D. L., \& Church, R. L. (1985). Transmission corridor location modelling. Journal of Transportation Engineering, 111, 114-130.

Hunter, G. J., \& Goodchild, M. F. (1997). Modeling the uncertainty of slope and aspect estimates derived from spatial databases. Geographical Analysis, 29(1), 35-49. https://doi.org/10.1111/j.1538-4632.1997. tb00944.x.

Kantner, J. (2012). Realism, reality, and routes: evaluating cost-surface and cost-path algorithms. In D. White \& S. L. Surface-Evans (Eds.), Least Cost Analysis of Social Landscapes: Archaeological Case Studies (pp. 225-238). Salt Lake City: University of Utah Press http://qut.eblib.com.au/patron/FullRecord.aspx? $\mathrm{p}=3443847$. Accessed 22 December 2019.

Kantner, J., \& Hobgood, R. (2003). Digital technologies and prehistoric landscapes in the American Southwest. In M. Forte \& P. R. Williams (Eds.), The reconstruction of archaeological landscapes through digital technologies: proceedings of the 1st Italy-United States workshop, Boston, Massachusetts, USA, November 1-3, 2001 (pp. 117-124). Oxford, England: Archaeopress.

Leon, J. X., Heuvelink, G. B. M., \& Phinn, S. R. (2014). Incorporating DEM uncertainty in coastal inundation mapping. PLoS ONE, 9(9), e108727. https://doi.org/10.1371/journal.pone.0108727.

Lewis, J. (2020). leastcostpath: modelling pathways and movement potential within a landscape (version 1.7.9). R. https://github.com/josephlewis/leastcostpath

Llobera, M., \& Sluckin, T. J. (2007). Zigzagging: theoretical insights on climbing strategies. Journal of Theoretical Biology, 249(2), 206-217. https://doi.org/10.1016/j.jtbi.2007.07.020. 
Marwick, B. (2017). Computational reproducibility in archaeological research: basic principles and a case study of their implementation. Journal of Archaeological Method and Theory, 24(2), 424 450. https:// doi.org/10.1007/s10816-015-9272-9.

Murrieta-Flores, P. (2012). Understanding human movement through spatial technologies. The role of natural areas of transit in the Late Prehistory of South-western Iberia. Trabajos de Prehistoria, 69(1), 103-122. https://doi.org/10.3989/tp.2012.12082.

Nackaerts, K., Govers, G., \& Loots, L. (1999). The use of Monte-Carlo techniques for the estimation of visibility. In L. Dingwall, S. Exon, V. Gaffney, S. Laflin, \& M. van Leusen (Eds.), Archaeology in the Age of the Internet. CAA97. Computer Applications and Quantitative Methods in Archaeology (pp. 6366). Oxford: Archaeopress.

Nicholson, C. (1861). The annals of Kendal: being a historical and descriptive account of Kendal and the neighbourhood: with biographical sketches of many eminent personages connected with the town. London/Kendal: Whitaker \& Co. https://archive.org/details/annalsofkendalbe00nich/. Accessed 22 December 2019.

Oliver, M. A., \& Webster, R. (2015). Basic steps in geostatistics: the Variogram and Kriging. Cham: Springer International Publishing. https://doi.org/10.1007/978-3-319-15865-5.

Ordnance Survey. (2017). OS Terrain 5 DTM [online]. https://digimap.edina.ac.uk/. Accessed 1 June 2017

Ordnance Survey. (2020). OS Terrain 50 DTM [online]. https://digimap.edina.ac.uk/. Accessed 5 Oct 2020.

Palmisano, A. (2017). Drawing pathways from the past: the trade routes of the old Assyrian caravans across Upper Mesopotamia and Central Anatolia. In F. Kulakoğlu, G. Barjamovic, \& K. R. Veenhof (Eds.), Movement, resources, interaction: proceedings of the 2nd Kültepe International Meeting, Kültepe, 26-30 July 2015: studies dedicated to Klaas Veenhof (pp. 29-48). Turnhout, Belgium: Brepols.

Parcero-Oubiña, C., Güimil-Fariña, A., Fonte, J., \& Costa-García, J. M. (2019). Footprints and Cartwheels on a Pixel Road: On the Applicability of GIS for the Modelling of Ancient (Roman) Routes. In P. Verhagen, J. Joyce, \& M. R. Groenhuijzen (Eds.), Finding the Limits of the Limes (pp. 291-311). Cham: Springer International Publishing. https://doi.org/10.1007/978-3-030-04576-0_14.

Pebesma, E. J. (2004). Multivariable geostatistics in S: the gstat package. Computers \& Geosciences, 30(7), 683-691.

Pebesma, E. J., \& Bivand, R. S. (2005). Classes and methods for spatial data in R. R News, 5(2), 9-13.

R Core Team. (2018). R: A language and environment for statistical computing. Viena, Austria: R Foundation for Statistical Computing https://www.R-project.org/.

Shepherd, M. (2004). From Hellgill to Bridge End: aspects of economic and social change in the Upper Eden Valley, 1840 - 95. Hatfield: Univ. of Hertfordshire Press.

Shotter, D. C. A. (2004). Romans and Britons in north-west England (New and rev. ed.). Lancaster: Centre for North-West Regional Studies, University of Lancaster.

Surface-Evans, S. L., \& White, D. (2012). An Introduction to Least Cost Analysis of Social Landscapes. In D. White \& S. L. Surface-Evans (Eds.), Least Cost Analysis of Social Landscapes: Archaeological Case Studies (pp. 1-10). Salt Lake City: University of Utah Press.

Talbert, R. J. A. (2000). Barrington atlas of the Greek and Roman world. Princeton, N.J: Princeton University Press.

Temme, A. J. A. M., Heuvelink, G. B. M., Schoorl, J. M., \& Claessens, L. (2009). Chapter 5 Geostatistical simulation and error propagation in geomorphometry. Developments in Soil Science, 33, 121-140). Elsevier. https://doi.org/10.1016/S0166-2481(08)00005-6.

Tennekes, M. (2018). tmap: Thematic maps in R. Journal of Statistical Software, 84(6), 1-39. https://doi.org/ 10.18637/jss.v084.i06.

Tobler, W. (1993). Three Presentations on Geographical Analysis and Modeling. Technical Report 93-1. Santa Barbara, CA: National Center for Geographic Information and Analysis. https://escholarship.org/ uc/item/05r820mz. Accessed 27 March 2021.

Verhagen, P. (2018). Spatial analysis in archaeology: moving into new territories. In C. Siart, M. Forbriger, \& O. Bubenzer (Eds.), Digital Geoarchaeology: New Techniques for Interdisciplinary HumanEnvironmental Research (pp. 11-25). Cham: Springer International Publishing. https://doi.org/10.1007/ 978-3-319-25316-9_2.

Verhagen, P., \& Jeneson, C. F. (2012). A Roman puzzle: trying to find the Via Belgica with GIS. In A. Chrysanthi, P. Murrieta-Flores, C. Papadopoulos, \& J. Huggett (Eds.), Thinking beyond the tool: archaeological computing and the interpretive process (pp. 123-130). Oxford: Archaeopress.

Verhagen, P., Nuninger, L., \& Groenhuijzen, M. R. (2019). Modelling of pathways and movement networks in Archaeology: an overview of current approaches. In P. Verhagen, J. Joyce, \& M. R. Groenhuijzen (Eds.), Finding the Limits of the Limes: Modelling Demography, Economy and Transport on the Edge of 
the Roman Empire (pp. 217-249). Cham: Springer International Publishing. https://doi.org/10.1007/9783-030-04576-0_11.

Wang, L., \& Liu, $\bar{H}$. (2006). An efficient method for identifying and filling surface depressions in digital elevation models for hydrologic analysis and modelling. International Journal of Geographical Information Science, 20(2), 193-213. https://doi.org/10.1080/13658810500433453.

Wechsler, S. P., \& Kroll, C. N. (2006). Quantifying DEM uncertainty and its effect on topographic parameterS. Photogrammetric Engineering \& Remote Sensing, 72(9), 1081-1090. https://doi.org/10. 14358/PERS.72.9.1081.

Wheatley, D., \& Gillings, M. (2002). Spatial technology and archaeology: the archaeological applications of GIS. New York: Taylor \& Francis.

White, D., \& Surface-Evans, S. L. (Eds.). (2012). Least cost analysis of social landscapes: archaeological case studies. Salt Lake City: University of Utah Press.

Whitehead, S., \& Elsworth, D. W. (2008). Investigation of part of the High Street Roman Road in Kentmer. Transactions of the Cumberland and Westmorland Antiqurian and Archaeological Society, 8, 241-246.

Yu, C., Lee, J., \& Munro-Stasiuk, M. J. (2003). Research article: extensions to least-cost path algorithms for roadway planning. International Journal of Geographical Information Science, 17(4), 361-376. https:// doi.org/10.1080/1365881031000072645.

Zhang, J., \& Goodchild, M. F. (2003). Uncertainty in geographical information. In London. New York: Taylor \& Francis http://site.ebrary.com/id/10053859. Accessed 16 July 2020.

Zhou, G., Esaki, T., Mitani, Y., Xie, M., \& Mori, J. (2003). Spatial probabilistic modeling of slope failure using an integrated GIS Monte Carlo simulation approach. Engineering Geology, 68(3-4), 373-386. https://doi.org/10.1016/S0013-7952(02)00241-7.

Zipf, G. K. (1949). Human behavior and the principle of least effort (pp. xi, 573). Oxford, England: AddisonWesley Press.

Publisher's Note Springer Nature remains neutral with regard to jurisdictional claims in published maps and institutional affiliations. 